\title{
Gintautè ŽIBĖNIENĖ
}

Mykolo Romerio universitetas

Mykolas Romeris University

\section{STUDIJŲ PROGRAMŲ \\ ATNAUJINIMO LIETUVOJE \\ APŽVALGA: \\ STUDENTŲ SAVARANKIŠKO \\ DARBO PLANAVIMAS}

REVIEW OF STUDY

PROGRAMME RENEWAL

IN LITHUANIA: PLANNING

STUDENTS' INDEPENDENT WORK

\section{SANTRAUKA}

Straipsnyje pristatoma pagal 2007-2013 m. Žmogiškųų išteklių plètros veiksmų programos 2 prioritetą "Mokymasis visą gyvenimą“ (toliau - Programa) atnaujintų pirmos ir antros pakopos studijų programų išorinio kokybès vertinimo rezultatai studentų savarankiško darbo planavimo aspektu. Atskleidžiama, kad atnaujinant studijų programas problemų kilo dèl savarankiško darbo metodų, užduočių ívairovès, suderinamumo su dalyko rezultatais, dalyko turiniu, apimtimi kreditais bei studentų savarankiško darbo vertinimo.

\section{PAGRINDINIŲ TERMINŲ APIBRÉŽIMAI}

- Studiju programa - tam tikros krypties studijų turinio, metodų ir materialiųu priemonių, studijoms pasitelkiamo akademinio ir profesinio personalo visuma ir jos aprašymas (Mokslo ir studiju ístatymas, 2009).

- Studiju programu atnaujinimas - studiju programos visumos ir jos aprašymo, t. y. visų struktūrinių dalių (bendrojo aprašo, dalykų aprašų ir kitų susijusių dokumentų, priedų)

\section{ABSTRACT}

The article introduces external quality assessment results of first cycle and second cycle study programmes renewed under the $\mathrm{Hu}$ man Resources Development Action Programme 2007-2013 priority direction 2 "Lifelong Learning" (hereinafter the "Programme") through the aspect of planning students' independent work. Problems faced when renewing study programmes are related to the methods of independent work, the variety of tasks, compatibility with learning outcomes at course unit level, its content, volume in credits and assessment of students' independent work.

\section{DEFINITIONS OF KEYTERMS}

- Study programme - a totality of the content, methods and material measures of studies of a certain study field, the academic and professional staff employed for the studies, and the description of the said totality (The Law of Science and Studies, 2009).

- Study programme renewal - systematic qualitative review, analysis and corrections of a totality of study programme and its description, 
sisteminga kokybinè peržiūra, analizè ir korekcijos siekiant patobulinti.

- Studentu savarankiško darbo planavimo vertinimas - studiju programos dokumentuose nurodomos informacijos apie studentų savarankiško darbo planavimą vertinimas pagal savarankiško darbo vertinimo kriterijus, nurodytus Lietuvos Respublikos Švietimo ir mokslo ministerijos 2010-09-30 dokumente Nr. SR-28-01-299.

- Ekspertas - kompetentingas asmuo, vertinantis atnaujinamas studiju programas; dalyvavęs projekto „Studiju sistemos analizè ir tobulinimas" mokymuose ir atliekantis atnaujinamų studijų programų tarpinį vertinimą pagal Švietimo ir mokslo ministerijos 2010-09-30 dokumente Nr. SR-28-01-299 suformuluotus Žmogiškųjų išteklių veiksmų programos 2 prioriteto „Mokymasis visą gyvenimą VP1-2.2-ŠMM-07-K „Studiju kokybès gerinimas, tarptautiškumo didinimas“, atnaujinamų studijų programų tarpinio vertinimo reikalavimus ir kriterijus.

- Tarpinio vertinimo ataskaita - rašytinè vertinimo ataskaita, eksperto parengta pagal atnaujinamų studijų programų tarpinio vertinimo reikalavimus ir kriterijus, nurodytus Lietuvos Respublikos Švietimo ir mokslo ministerijos 2010-09-30 dokumente Nr. SR28-01-299, suformuluotus Žmogiškųų išteklių veiksmų programos 2 prioriteto „Mokymasis visą gyvenimą" VP1-2.2-ŠMM-07-K „Studijų kokybės gerinimas, tarptautiškumo didinimas". i.e. all structural parts (general description, course unit descriptions and other related documents and appendices), with the aim of improvement.

- Assessment of student independent work planning - assessment of information on student independent work planning provided in the documents of a study programme in accordance with criteria of independent work assessment identified in the document No. SR-28-01-299 (of 30-09-2010) of the Ministry of Education and Science of the Republic of Lithuania.

- Expert - a competent individual who assesses renewed study programmes; a person who participated in training sessions of the project "Analysis and Improvement of the System of Studies" and conducts interim assessment of renewed study programmes in accordance with requirements and criteria for interim assessment of renewed study programmes that were set in the document No. SR-28-01-299 (of 30-09-2010) of the Ministry of Education and Science of the Republic of Lithuania under the Operational Programme for the Development of Human Resources 2007-2013 $2^{\text {nd }}$ Priority "Life-long Learning" VP1-2.2- MM-07-K measure "Enhancing of the Quality of Studies, Strengthening of Internationality".

- Interim assessment report - a written assessment report that an expert prepares following requirements and criteria for interim assessment of renewed study programmes that were set in the document No. SR-28-01-299 (of 3009-2010) of the Ministry of Education and Science of the Republic of Lithuania under the Operational Programme for the Development of Human Resources 2007-2013 $2^{\text {nd }}$ Priority "Life-long Learning" VP1-2.2- MM07-K measure "Enhancing of the Quality of Studies, Strengthening of Internationality". 


\section{IVADAS}

Mokymosi visą gyvenimą idejjų kontekste ypač ryškus nuolatinis kokybès siekinys. Nors, kaip rodo teorinès literatūros analizè, poreikis vertinti atsirado dar XVII a. (Rossi ir kt., 2003), iš tikrųjų domètis studijų kokybe imta tik nuo XX a., tobulejant studijų kokybès vertinimo metodams, vykstant ideologiniams, politiniams ir demografiniams pokyčiams. Lietuvoje atkūrus nepriklausomybę, reformuojant aukštojo mokslo sistemą, daug dèmesio buvo skiriama aukštosiose mokyklose igyvendinamų studiju programų kokybei užtikrinti. Siekiant kokybiškos veiklos, aukštosioms mokykloms būtinas nuolatinis kokybès siekinys. Atliepdamos rinkos poreikius ir noredamos būti konkurencingos, aukštosios mokyklos sistemingai atnaujina studijų programas, kuria naujas. Studijų programų atnaujinimas Lietuvoje ypač suaktyvèjo vykdant 2007-2013 m. Žmogiškujju ištekliu plètros veiksmų programos veiklas, paskatinusias naujus kokybinius pokyčius studiju programose, ir nuo $2011 \mathrm{~m}$. rugsèjo $1 \mathrm{~d}$. Lietuvos aukštosiose mokyklose įdiegus Europos kreditų perkèlimo ir kaupimo sistemą (angl. European Credit Transfer and Accumulation System - ECTS) (Laipsni suteikiančių pirmosios pakopos ir vientisųjų studijų programų bendrujų reikalavimų aprašas, 2010; 2007-2013 m. Žmogiškujų ištekliu plètros veiksmų programos 2 prioriteto „Mokymasis visą gyvenimą " VP1-2.2-ŠMM-07-K priemonės „Studijų kokybės gerinimas, tarptautiškumo didinimas" projektų finansavimo sąlygų aprašas, 2010). Studijų programų atnaujinimas Lietuvoje skatinamas nacionaliniu (parengti nacionaliniai dokumentai, rekomendacijos atnaujinamų studijų programoms vertinti, skiriamos Europos Sąungos lèšos aukštosioms mokykloms, vykdančioms studiju programų atnaujinimą, parengti ekspertai atnaujinamų studiju programoms vertinti) bei tarptautiniu (Bolonijos proceso

\section{INTRODUCTION}

Constant aiming at quality has become extremely important in the context of life-long learning. Although the analysis of theoretical literature has revealed that a need to assess developed back in the $17^{\text {th }}$ century (Rossi et al., 2003), actual interest in the quality of studies only started in the $20^{\text {th }}$ century when assessment methods for quality of studies were improved and ideological, political and demographic changes took place. Reforms of the system of higher education after the reestablishment of Lithuanian independence focused on quality assurance in study programmes delivered at higher education institutions. In order to achieve high-quality activity, higher education institutions have to constantly aim at quality. In order to reflect market needs and be competitive, higher education institutions perform systematic renewal of study programmes and design new ones. Renewal of study programmes in Lithuania has intensified since implementing activities of the Operational Programme for the Development of Human Resources 2007-2013 that inspired qualitative changes in study programmes and after introducing the European Credit Transfer and Accumulation System (ECTS) to Lithuanian higher education institutions on the $1^{\text {st }}$ on September in 2011 (Laipsnị suteikiančių pirmosios pakopos ir vientisujjų studijų programų bendrųjų reikalavimų aprašas, 20101; 2007-2013 m. Žmogiškujų išsteklių plètros veiksmų programos 2 prioriteto „Mokymasis visą gyvenimą“ VP1-2.2-ŠMM-07-K priemonès „Studijų kokybès gerinimas, tarptautiškumo didinimas" projektų finansavimo sąlygu aprašas, $2010^{2}$ ). Renewal of study programmes in Lithuania is

1 In EN: Requirements for study programs of first cycle and integrated studies, 2010

2 In EN: Description of financial conditions for projects under 2007-2013 Human Resource Development Programme 2nd priority "Lifelong Learning" VP1-2.2-ŠMM07-K measure "Study Quality Improvement, International Increase”, 2010 
dokumentai, Europos švietimo struktūrų suderinimo (angl. Tuning Educational Structures in Europe)) projekto rezultatai, Europos kreditų perkèlimo ir kaupimo sistema (ECTS) bei Aukštojo mokslo kokybès užtikrinimo agentūros (angl. The Quality Assurance Agency for Higher Education) rekomendacijos lygmenimis.

Remiantis moksline literatūra, curriculum teorija, jau senokai moksliškai pagrịstas sistemingas studijų programų turinio tobulinimas (Bamberger, 2000; Royse, Thyer,1996), šią svarbą taip pat pagrindè studijų turinio (angl. curriculum) teorijos tyrinètojai (Kerr, 1967; Laužackas, 2000; Pukelis, 1999; Pukelis, Sajienè, 2000; Tyler, 1949 ir kt.). Studiju programų atnaujinimo klausimai užsienyje nagrinejjami gana seniai (Losak, Burns, 1971; Windle, Ochberg, 1975). Lietuvoje šie tyrimai taip pat atliekami: socialinių pedagogų neuniversitetinio rengimo ir jo praktinio realizavimo tendencijas aptarè R. Čiapukas (2005), neuniversitetinių studijų programų rengimo bei kokybès vertinimo teorinius ir praktinius aspektus - G. Žibènienè (2006), studijų programų rengimo ir atnaujinimo metodines nuostatas bei praktinị igyvendinimą rengiant ir atnaujinant mokymo / studiju programas išsamiai analizavo R. Laužackas (2008), gebejimo, kompetencijos, mokymosi / studijų, rezultato, kvalifikacijos ir kompetentingumo reiškinių struktūrą - K. Pukelis (2009) ir kt.

Bolonijos proceso 2020 dokumentuose akcentuojama aktualija - individualizuoti i studentą nukreiptas studijas, dèl to svarbūs kokybiniai pokyčiai planuojant ir igyvendinant savarankišką studentų darbą (Bologna beyond 2010). Daug Lietuvos aukštųjų mokyklų panaudojo Programos léšas studijų programoms atnaujinti. Šis procesas pagal Programos gaires prasidèjo vos prieš kelerius metus, o studiju programų tarpinis vertinimas - tik prieš trejus metus. Tad stinga studijų programų atnaujinimo patirties apžvalgos, analizès apie studijų programų atnaujinimą promoted at national (documents and recommendations for assessment of renewed study programmes are prepared, experts are trained to assess renewed study programmes) and international (Bologna documents, outcomes of the project Tuning Educational Structures in Europe, European Credit Transfer and Accumulation System - ECTS, and recommendations of the Quality Assurance Agency for Higher Education) levels.

Systematic enhancement of curriculum of study programmes was validated in scientific literature, curriculum theory a long time ago (Bamberger, 2000; Royse, Thyer, 1996). Its importance was also validated by researchers of the curriculum theory (Kerr, 1967; Laužackas, 2000; Pukelis, 1999; Pukelis, Sajienè, 2000; Tyler, 1949 et al.). Various aspects of study programme renewal have been analysed abroad for quite a while (Losak, Burns, 1971; Windle, Ochberg, 1975). Such researches are also conducted in Lithuania: Čiapukas (2005) discussed non-university training of social pedagogues and its practical realisation, Žibèniené (2006) researched theoretical and practical aspects of designing non-university study programmes and quality assessment, Laužackas (2008) analysed methodological provisions of study programme design and renewal as well as their practical use when designing and renewing study programmes, Pukelis (2009) analysed the structure of phenomena of ability, competency, learning / study outcome, qualification and competence etc.

Bologna Process 2020 documents emphasise individualisation of student-centred studies, focusing on quality-related transformation in planning and implementing students' independent work (Bologna beyond 2010). A significant number of Lithuanian higher education institutions used funds of the Programme to renew study programmes. Following the Programme guidelines, this process has started several years ago and interim assessment of study programmes - only three years ago. Thus the lack of 
igyvendinant Programą bei diegiant ECTS. ŠMM ir aukštųjų mokyklų iniciatyva, $2011 \mathrm{~m}$. gegužès mèn. vykusiuose seminaruose L. Leonas, A. Rauckienè, P. Grecevičius analizavo ir aptarè pirmąji pusmeti vertintų atnaujinamų studijų programų patirti, apibendrino ekspertu parengtas tarpinio vertinimo ataskaitas pagal išskirtas ekspertams privalomas vertinti keturias sritis: „Programos tikslai ir studijų rezultatai ${ }^{1 “ ;}$ „Programos sandara“; „Studijų eiga“; „Programos vadyba“ (Seminaro „Atnaujinamų studijų programų tarpinio vertinimo rezultatai“ medžiaga, 2011). Programos vykdymo laikotarpyje studijų programų rengimo ir atnaujinimo aktualijas, pokyčius analizavo K. Pukelis (2011), G. Žibėnienè (2011), sąvokos Learning Outcome darninimo lietuvių kalboje problematiką K. Pukelis, A. Smetona (2011), studentų studijavimo pasiekimų vertinimą - I. Savickiené (2011). Studijų programų atnaujinimas diegiant ECTS aptartas Vilniaus universiteto 2009-2012 m. vykdomo nacionalinio projekto „Europos kreditų perkèlimo ir kaupimo sistemos (ECTS) nacionalinès koncepcijos parengimas: kreditų harmonizavimas ir mokymosi pasiekimais grindžiamų studijų programų metodikos kūrimas bei diegimas“ igyvendinimo laikotarpiu. $2013 \mathrm{~m}$. rugsèjo mèn. Švietimo ir mokslo ministerijos i aukštąsias mokyklas išsiųstoje R. Bartkevičiaus su kolegomis (2013) parengtoje apžvalgoje rekomenduojama aiškiau planuoti savarankišką studentų darbą, bet daugiau nedetalizuojama. Nors gausu pranešimų, informacinių ar viešinimo straipsnių apie studijų programų atnaujinimo gaires, ECTS įdiegimą, tačiau studijų programu atnaujinimo patirtis, ypač studentų savarankiško darbo planavimo aspektu, mokslinèje literatūroje nepakankamai išsamiai analizuota, taip pat nepakankamai aprašyta Programos vykdymo laikotarpiu.

1 Cituojamame tekste vartojamas neteisingas learning outcomes vertimas ị lietuvių kalbą, todèl sąvoka „siekiniai“ pakeista i „rezultatai“. reviews of study programme renewal and analyses of study programme renewal under implementation of the Programme and implementing ECTS can be noted. In the seminars that were organised under the initiative of the Ministry of Education and Science and higher education institutions in May, 2011, Leonas, Rauckienè, and Grecevičius analysed and discussed study programme renewal practice in the first half of the year, summarised expert report of interim assessment in accordance with four areas that experts must assess, i.e. "Programme aims and learning outcomes"; "Programme structure"; "Study progress"; "Programme management" (Seminaro „Atnaujinamų studiju programu tarpinio vertinimo rezultatai“ medžiaga, 2011 ${ }^{4}$ ). During the period of Programme implementation, Pukelis (2011), Žibėnienè (2011) analysed study programme design and renewal related issues and changes; Pukelis, Smetona (2011) researched issues related to harmonisation of the concept of learning outcome in Lithuania educational culture; Savickiene (2011) analysed assessment of students' learning achievements. Study programme renewal while introducing ECTS was discussed in the national project "Preparing National Conception of the European Credit Transfer and Accumulation System (ECTS): credit harmonisation and design and implementation of learning achievements based methodology of study programmes", implemented by Vilnius University in 20092012 m. In September, 2013, the Ministry of Education and Science provided higher education institutions with a review prepared by Bartkevičius et al. (2013) in which they recommend to plan students' independent work more accurately. However, no detailed information is provided. Irrespective of various presentations, informative and public articles on the

\footnotetext{
3 Incorrect translation of learning outcomes into Lithuanian was used in the text; thus the Lithuanian term "siekiniai" (in EN: objectives, aims) was changed into "rezultatai" (EN: outcomes, results).

4 In EN: Material of seminar "Results of interim assessments of study programmes under renewal”, 2011
} 
T. Bulajeva ir kolegos (2011) analizavo studijų programų atnaujinimą: kompetentingumų plètotès ir studijų rezultatų ${ }^{2}$ vertinimo aspektu, tačiau tai metodinè priemoné, kurioje nenagrinėjama konkreti studijų programų atnaujinimo praktika, Lietuvoje kilusios problemos atnaujinant studiju programas. Tačiau studentų savarankiško darbo klausimai išsamiau aptarti, atskleisti K. Pukelio su kolegomis (2011) parengtoje metodikoje, pristatant savarankiško studijavimo galimybes panaudojant elektronines priemones.

Studentų savarankiško darbo problematika, nesiejant su atnaujinamomis studiju programomis, Lietuvoje analizuota ivvairiais aspektais: A. Budrienè ir J. Margelienè (2010) analizavo integruoto savarankiško darbo taikymą studijų procese, A. Pečiūrienè, R. Radlinskaitè, D. Žvinakevičienė (2010) - savarankiško darbo profesinio bakalauro studiju procese aktualijas, R.Augaitienè, E. Augutienè, J. Bučelienè (2012) - studentu savarankiško darbo ittaką mokantis matematikos, L. Rupšienè, A. Mažionienè (2011) tyrè studentų požiūrị i savarankišką darbą, N. Jurkšaitienè (2010) - studentų savarankiškumo ugdymo aspektus ir kt. Studijų programų atnaujinimo patirties apžvalga Programos igyvendinimo laikotarpiu studentų savarankiško darbo planavimo aspektu nèra išsami, nors tai ypač svarbu aukštoje mokykloje siekiant atliepti Bolonijos proceso aktualijas ir konstruktyvistinių studijų sieki. L. Rupšienè, A. Mažionienè pastebi, kad „studentų savarankiškas darbas ypač aktualizavosi keičiantis paradigmoms iš tradicinès mokymo it konstruktyvistinę mokymosi“ (2011, p. 152).

2 Autoriu vartojami „siekiniai“ pakeisti i „studiju rezultatus“, „kompetencijos“ - $\mathfrak{i}$ „kompetentingumus“, nes tai teisingi terminu „learning outcome“ ir „competence“ atitikmenys. Kita vertus, taip ivardijama ir nacionaliniuose teisès aktuose, pvz., Studijų kokybès vertinimo centro direktoriaus issakyme Dèl ketinamos vykdyti studijų programos aprašo rengimo, jos išorinio vertinimo ir akreditavimo metodikos patvirtinimo $2011 \mathrm{~m}$. lapkričio 28 d. Nr. 1-01-157, „Studiju terminų žodyne“ ir kitur. guidelines of study programme renewal and ECTS implementation, study programme renewal practice, especially on planning students' independent work, has not been sufficiently analysed in scientific literature and described over the period of Programme implementation. Bulajeva et al. (2011) analysed renewal of study programmes through the perspective of assessing the development of competences and learning outcomes ${ }^{5}$; however, this methodological tool does not analyse renewal practice of a specific study programme and problems faced when renewing study programmes in Lithuania. Various aspects of students' independent work are thoroughly discussed in the methodology prepared by Pukelis et al. (2011) where they introduce the use of electronic tools for independent learning.

Various issues of students' independent work have been analysed in Lithuania without incorporating the aspect of renewable study programmes. Budrienè and Margelienè (2010) analysed the use of integrated independent work in the study process; Pečiūrienè, Radlinskaitè and Žvinakevičienè (2010) studied independent work in the process of vocational bachelor studies; Augaitienè, Augutienè, and Bučelienè (2012) researched the influence of students' independent work when learning mathematics; Rupšienè and Mažionienè (2011) analysed students' opinions on independent work; Jurkšaitienè (2010) analysed aspects of independence development etc. Reviews of study programme renewal during the Programme implementation period lack a

\footnotetext{
5 Terms used by authors were changed: Lithuanian "siekiniai" (in EN: objectives, aims) to "studiju rezultatai" (in EN: learning outcomes), Lithuanian "kompetencijos" (in EN: competencies) to "kompetentingumai" (in EN: competences) as these are the correct equivalents of "learning outcome" and "competence". Besides, these terms are also used in national legal acts, e.g. order of the Director of the Centre for Quality Assessment in Higher Education On the Approval of the Methodology for the Preparation of the Description, External Review and Accreditation of New Study Programmes (28th of November, 2011, No. 1-01-157), "Dictionary of Study Terms" etc.
} 
Todèl straipsnyje keliama problema - Programos igyvendinimo laikotarpiu Lietuvoje nepakankamai išanalizuota atnaujinamų studijų programų patirtis studentų savarankiško darbo planavimo aspektu. Tyrimo objektas studentų savarankiško darbo planavimas atnaujinamose studijų programose.

Tyrimo tikslas - aptarti studijų programų atnaujinimą studentų savarankiško darbo aspektu, Lietuvoje igyvendinant Programą. Tyrimo uždaviniai: pristatyti studijų programų atnaujinimą pagal 2007-2013 m. Žmogiškųjų išteklių plètros veiksmų programos 2 prioritetą; atskleisti ekspertų įvardytas problemas, trūkumus, pastebètus pagal Programą atnaujinamose studijų programose planuojant studentų savarankišką darbą; pristatyti studijų programas atnaujinusių asmenų ìvardytas problemas, trūkumus planuojant studentų savarankišką darbą pagal Programą atnaujinamose studijų programose.

Tyrimo organizavimas ir metodai. Taikyta literatūros šaltinių ir teisès aktų analizè studijų programų rengimo ir atnaujinimo tematika, ekspertinių tarpinių vertinimų ataskaitų (angl. content) analizé, pokalbis su studijų programas atnaujinančiais asmenimis. Ekspertinès tarpinio vertinimo ataskaitos buvo analizuojamos remiantis tradicine (kokybine) teksto analize (Mayring, 2000), kai analizė vykdoma sistemiškai, daug kartų skaitant tekstą. Taip pat buvo remiamasi Žmogiškųų išteklių veiksmų programos 2 prioriteto <...> kriterijais (2010) studentų savarankiško darbo aspektu. Tyrimas organizuotas dviem etapais. 2011-2012 m. išanalizuotos 24 atnaujintų pirmos ir antros pakopos studijų programas (kolegijų ir universitetų) vertinusių ekspertų tarpinio vertinimo ataskaitos. Taikyta ekspertų imtis, asmenys ịtraukti į ekspertų sąrašą (Studijų programų, atnaujinamų <...>, 2010). Straipsnio autore taip pat atliko studijų programų tarpinius vertinimus. Vertintų studijų programų pavadinimai neịvardijami siekiant konfidencialumo, nes ekspertų teisès more comprehensive analysis of the aspect of independent work planning even though this aspect is very important when reflecting the Bologna process ideas and objectives of constructivist studies. Rupšienė and Mažionienè note that "students' independent work ideas were updated through transformation of paradigms from traditional teaching to constructivist learning" (2011, p.152). Thus the following problem is highlighted in the article: during the Programme implementation period in Lithuania, study programme renewal practices were insufficiently analysed through the aspect of students' independent work planning. Research object: students' independent work planning in renewed study programmes.

Research aim: to discuss renewal of study programmes through the aspect of students' independent work when implementing the Programme in Lithuania. Research tasks: to introduce study programme renewal under the Human Resources Development Action Programme 2007-2013 priority direction 2; to reveal problems and disadvantages that experts identified in planning students' independent work in study programmes renewed under the Programme; to introduce problems and disadvantages that individuals who renewed study programmes identified in planning students' independent work in study programmes renewed under the Programme.

Research organisation and methods. The following research methods were applied: analysis of literature resources and legal acts on study programme design and renewal, content analysis of expert interim assessment reports, interview with individuals who renew study programmes. Content of expert interim assessment reports was analysed on the basis of traditional (qualitative) text analysis (Mayring, 2000), when analysis is conducted systematically, reading text repeatedly. Besides, the criteria of the Human Resources Development Action Programme 2007-2013 priority direction 2 (2010) were applied through the aspect 
viešinti informaciją yra ribotos. Skirtumai tarp pirmos ir antros pakopos bei koleginiu ir universitetinių studijų programų tarpinio vertinimo ataskaitų nebuvo ryškūs, tad šiame straipsnyje studijų programų atnaujinimo patirtis ir šių programų ekspertinio tarpinio vertinimo ataskaitos aptariamos bendrai. Išsamiau aiškinantis problemą, kalbètasi su šešias studijų programas atnaujinančių darbo grupių nariais - 21 asmeniu. Tyrimo imtis patogioji, nes pasirinkti aukštosios mokyklos darbuotojai, kurie pagal Programą atnaujino studijų programas dèsto ir dirba visu etatu, kuriuos buvo nesunku rasti atsižvelgiant i dominančias charakteristikas. Tyrimo etika: tyrimas atliktas laikantis savanoriškumo principo, tiriamiesiems patogioje aukštosios mokyklos aplinkoje ir patogiu laiku, gavus juc sutikimus ir leidimus.

1

STUDIJŲ PROGRAMŲ

ATNAUJINIMAS PAGAL 2007-2013

M. ŽMOGIŠKŲJŲ IŠTEKLIŲ PLĖTROS VEIKSMŲ PROGRAMOS 2 PRIORITETĄ

Aukštosios mokyklos, sèkmingai parengusios projektus pagal 2007-2013 m. Žmogiškųjų išteklių plètros veiksmų programos 2 prioritetą „Mokymasis visą gyvenimą“ <...> Žin. (2010), igijo teisę Europos Sąjungos lešomis atnaujinti studijų programas. of students' independent work. Research was organised in two stages. In 2011-2012, 24 expert interim assessment reports on renewed first cycle and second cycle study programmes (at colleges and universities) were analysed. Expert sample was applied, putting individuals into an expert list (Studiju programu, atnaujinamu $<\ldots>, 2010^{6}$ ). The author of the article also performed interim assessments of study programmes. To assure confidentiality, names of assessed study programmes were not included as experts have limited rights to publish information. No significant differences were noted in interim assessment reports of the first and second cycle, college and university study programmes. Thus only general descriptions of study programme renewal practices and expert interim assessment reports are provided in the article. A more comprehensive analysis of the problem involved interviews with 21 members of work groups responsible for the renewal of six study programmes. A convenience sampling was applied as the selected higher education institution employees, who renewed study programmes under the Programme, teach and work full time and were easy to find following certain characteristics. Research ethics: research was conducted on a voluntary basis, in a comfortable environment at a higher education institution at convenient time, with a permission of participants.

1

RENEWAL OF STUDY PROGRAMMES UNDER THE HUMAN RESOURCES DEVELOPMENT ACTION PROGRAMME 2007-2013 PRIORITY DIRECTION 2

After successfully designing projects under the Human Resources Development Action Programme 2007-2013 priority direction

\footnotetext{
6 In EN: Experts and advisers for interim assessment of study programmes under renewal in projects of EU structural funds, 2010
} 
Remiantis „Atnaujinamų studijų programų tarpinio vertinimo ataskaitos gairèmis“ (2011) bei Žmogiškųjų išteklių veiksmų programos 2 prioriteto „Mokymasis visą gyvenimą" <..> (2010) studijų programų atnaujinimas turi vykti keturiomis kryptimis: „Programos tikslai ir studijų rezultatai“; „Programos sandara“; „Studijų eiga“; „Programos vadyba“; išskirtinis dèmesys kreipiamas i konkrečios aukštosios mokyklos vykdomame projekte numatytus atnaujinimus. Kiekvieną vykdomo projekto metu atnaujintą studijų programą turi vertinti bent $\mathrm{du}$ ekspertai. Aukštosios mokyklos, siekdamos visapusiško, kokybiško vertinimo, kvietè skirtingus ekspertus: konkrečios srities specialistą ir edukologą. Kiekvienos iš keturių vertinimo sričių atnaujinimo sèkmingumui ivertinti parengtos Mokslo ir studijų stebėsenos ir analizès centro (toliau MOSTA) vertinimo rekomendacijos, kurios apibrèžia ekspertų veiklos gaires. Ekspertai atliko vertinimą pagal tuos pačius kriterijus, nurodytus Lietuvos Respublikos Švietimo ir mokslo ministerijos 2010-09-30 dokumente Nr. SR-28-01-299 ir MOSTOS vertinimo rekomendacijas. Straipsnyje studijų programų atnaujinimo apžvalga studentų savarankiško darbo planavimo aspektu pateikta pagal iškilusias dažniausias atnaujinimo problemas, kurias minèjo studijų programas vertinę ekspertai bei jas rengę studijų programos rengimo darbo grupių nariai (1 lentelè).
2 "Lifelong Learning" <...> (2010), higher education institutions could renew study programmes with funds from the European Union. Following "Guidelines for Interim Assessment Reports of Renewed Study Programmes" (2011) and Human Resources Development Action Programme 2007-2013 priority direction 2 "Lifelong Learning" <...> (2010), renewal of study programmes should cover four areas: "Programme aims and learning outcomes"; "Programme structure"; "Study progress"; "Programme management". Attention is drawn to renewals set in the project implemented by a particular higher education institution. Every renewed study programme has to be assessed by at least two experts. To achieve comprehensive and highquality assessment, higher education institutions invited different experts: a specialist of a specific field and an education researcher. Research and Higher Education Monitoring and Analysis Centre (hereinafter MOSTA) prepared assessment recommendations to evaluate success of renewal of each assessment area that define expert activity guidelines. Experts performed assessment under the criteria set in the document No. SR-28-01-299 (of 30-092010) of the Ministry of Education and Science of the Republic of Lithuania and MOSTA assessment recommendations. In this article, content of study programme renewal is presented through the aspect of students' independent work planning, focusing on most common renewal issues that were identified by experts who assessed programmes and members of work groups responsible for study programme designing (Table 1). 
1 lentelè. Ekspertų bei studijų programas atnaujinusių asmenų išvardytos problemos atnaujinamose studijų programose planuojant studentų savarankišką darbą

Table 1. Students' independent work planning issues in renewable study programmes as presented by experts and individuals who renewed study programmes

\begin{tabular}{|c|c|}
\hline EKSPERTŲ IŠVARDYTOS PROBLEMOS & $\begin{array}{l}\text { STUDIJŲ PROGRAMAS ATNAUJINUSIŲ ASMENŲ IŠVARDYTOS } \\
\text { PROBLEMOS }\end{array}$ \\
\hline $\begin{array}{l}\text { Nepateikiami studentų savarankiško darbo metodai. } \\
\text { Nepakankama studentų savarankiško darbo metodų ivairovè. } \\
\text { Studentu savarankiškas darbas nepakankamai suderintas su } \\
\text { dalyko rezultatais. } \\
\text { Nèra pateikiami studentu savarankiško darbo vertinimo kriterijų. } \\
\text { Skirtingo išsamumo informacija apie planuojamą studentų } \\
\text { savarankišką darbą. } \\
\text { Planuojamas savarankiškas darbas nèra pakankamai suderintas } \\
\text { su dalyko kreditais, nepakankamai optimaliai paskirstytas laikas }\end{array}$ & $\begin{array}{l}\text { Nebuvo suteikta pakankamai informacijos, kaip ir ką reikia rašyti } \\
\text { apie studentu savarankišką darbą. } \\
\text { Nepakankamai aišku, kur, kurioje dalyko aprašo dalyje nurodyti } \\
\text { savarankišką darbą ir kiek išsamiai aprašyti (programos apraše, } \\
\text { dalyko aprašuose, individualiuose teminiuose planuose ar kt.) } \\
\text { Neaiškumai dèl dalyko rezultatų sąsaju su savarankišku darbu } \\
\text { (pvz., ar savarankišką darbą numatyti kiekvienam dalyko rezulta- } \\
\text { tui). Nepakankamai aišku, kokie inovatyvūs savarankiško darbo } \\
\text { metodai. }\end{array}$ \\
\hline ISSUES IDENTIFIED BY EXPERTS & $\begin{array}{l}\text { ISSUES IDENTIFIED BY INDIVIDUALS WHO RENEWED STUDY } \\
\text { PROGRAMMES }\end{array}$ \\
\hline $\begin{array}{l}\text { No students' independent work methods are provided. } \\
\text { Insufficient variety of students' independent work methods. } \\
\text { Students' independent work does not sufficiently correspond to } \\
\text { course unit outcomes. } \\
\text { No assessment criteria for assessing students' independent work } \\
\text { are provided. } \\
\text { The level of detailed information regarding planned students' } \\
\text { independent work differs. } \\
\text { Planned independent work does not sufficiently correspond to } \\
\text { course unit credits; time distributed insufficiently. }\end{array}$ & $\begin{array}{l}\text { Insufficient information on how and what has to be written about } \\
\text { students' independent work. } \\
\text { Unclear where (which part of the description) independent work } \\
\text { has to be put and how comprehensive its description should be } \\
\text { (in programme description, course unit description, individual } \\
\text { topics etc.) } \\
\text { Unclear links between outcomes at course unit level and inde- } \\
\text { pendent work (e.g. if independent work should be planned for } \\
\text { each outcome). Unclear innovative independent work methods. }\end{array}$ \\
\hline
\end{tabular}

2

EKSPERTŲ IŠVARDYTOS PROBLEMOS, TRŪKUMAI PLANUOJANT STUDENTU SAVARANKIŠKA DARBĄ PAGAL PROGRAMA ATNAUJINAMOSE STUDIJŲ PROGRAMOSE

Vertindami studijų programas, atnaujintas pagal Programos lèšs, ir rengdami tarpinio vertinimo ataskaitas, ekspertai turéjo nustatyti, ar išvardyti studento savarankiško darbo metodai ir (arba) užduotys, susieti su numatomais studijų dalyko ir (arba) modulio rezultatais bei jų vertinimo metodais ir kriterijais, ar siūloma savarankiško darbo metodų ir (arba) užduočių ìvairovè užtikrinant studentams pasirinkimo galimybes (Žmogiškưjų išteklių veiksmų programos 2 prioriteto „Mokymasis visą gyvenimą“ < <..>,

\section{STUDENTS' INDEPENDENT WORK PLANNING ISSUES IN STUDY PROGRAMMES RENEWED UNDER THE PROGRAMME, AS PRESENTED BY EXPERTS}

When assessing study programmes renewed by the Programme funds and preparing reports of interim assessment, experts had to determine whether presented students' independent work methods and (or) tasks are related to intended course unit and (or) module outcomes and their assessment methods and criteria, as well as whether students have a variety of independent work methods and (or) tasks to choose from (Žmogiškujju išteklių veiksmų programos 2 prioriteto „Mokymasis 
2010). Išvardyti kriterijai siejasi su K. Pukelio ir kolegų (2011) išskirtais pagrindiniais savarankiško studentų darbo organizavimo principais: dèstytojų vaidmens apibrèžtumas studentams studijuojant savarankiškai; konstruktyvizmo bei pragmatizmo idejjomis grịstas požiūris įstudijavimą; studiju rezultatais paremtas požiūris; studijavimo formų ìvairové; studijavimo metodų ivvairove; galimybė bendradarbiauti; vertinimo objektyvumas; konsultacijų rengiant savarankiškus darbus nuoseklumas.

Daugiau nei pusejje atnaujintų studijų programų (17 iš 24) studentų savarankiško darbo metodai nebuvo atskirai išskirti ir tiesiogiai ịvardyti, tačiau studijų dalyko rezultatų lenteleje buvo bendrai nurodyti studijų metodai, iš kurių - daug tinkamų studentų savarankiškam darbui. Dviejose studijų programose, atnaujintų dalykų aprašuose kaip savarankiško darbo metodai ir užduotys buvo nurodyta: koliokviumas, egzaminas, laboratorinis darbas. Šiuo atveju studijų programas atnaujinantys asmenys kaip savarankišką darbą ịvardijo studentų veiklos formas ir studijavimo pasiekimų vertinimą. Atnaujinamose studijų programose savarankiško darbo metodai dažniausiai nepasižymèjo didele îvairove, dominavo referatas, „studento individuali veikla pagal paskirtas užduotis“, pranešimas, „ivairios kūrybinès užduotys“, „užduočių atlikimas“. Atnaujinamose studijų programose turètų būti numatyta didesnè savarankiško darbo metodų įvairovè derinant su studiju procesu, dalyko turiniu, numatomais pasiekti dalyko rezultatais. Nedažnai numatyti studentų savarankiškam darbui Europos Sajungos aukštosiose mokyklose rekomenduojami: apžvalgos, esè, recenzija, mokymosi dienoraščiai, praktinių duomenų rinkimo ataskaitos, įvairių mokslo darbų kritinis vertinimas, atvejo analizè, projektai (Tuning: Europos švietimo struktūrų suderinimas, 2010) bei aplankas (portfolio), studentų prezentacijos (Pukelis ir kt., 2011). Taip visą gyvenimą “ < _..>, 20107). Presented criteria are related to key principles of students' independent work organisation identified by Pukelis et al. (2011): defined teacher's role in students' independent studying; constructivism and pragmatism based approach to learning; learning outcomes based approach; variety of studying forms; cooperation possibilities; objective assessment; consistent consultations during independent works.

In more than a half of renewed study programmes (17 out of 24), students' independent work methods were not separately distinguished and directly identified. General learning methods, the majority of which are suitable for students' independent work, were presented in the description of learning outcomes at course unit level. In two study programmes, descriptions of renewed course unit involved the following independent work methods and tasks: mid-term test, exam, lab work. In this case individuals who renew study programmes identified independent work as forms of student activity and assessment of learning achievements. Renewed study programmes did not involve a great variety of independent work methods: paper, "student's individual activity by given tasks", "various creative tasks", and "performing tasks". Renewed study programmes should involve a greater variety of independent work methods, coordinating them with a study process, curriculum, and formulated learning outcomes. Rarely are recommended popular in EU higher education institutions following independent work methods: reviews, essay, learning diaries, practical data collection reports, critical assessment of various scientific works, case analysis, projects (Tuning: Europos švietimo struktūrų suderinimas, 20108)

\footnotetext{
7 In EN: Requirements and criteria for interim assessment of study programmes under renewal in projects under 2007-2013 Human Resource Development Programme 2nd priority "Lifelong Learning" VP1-2.2-ŠMM-07-K measure "Study Quality Improvement, International Increase", 2010 8 In EN: Tuning Educational Structures in Europe, 2010
} 
pat studijų programas atnaujinantys asmenys turètų apsvarstyti, ar nereikètų ypač paplitusi referatą (daroma prielaida, kad tai klasikinis referuojamasis referatas) keisti į mokslini referatą ar kitus jo tipus, labiau atitinkančius bakalauro ar magistro studijų programos turinị. Tai sietųsi su R. Augaitienès ir kolegu (2012) pastebejjimu, kad savarankišką darbą reikètu suprasti kaip daugiaplanę savarankišką besimokančiojo veiklą. P. Grecevičius (2011), analizavęs atnaujinamų studijų programų tarpines ataskaitas, taip pat pastebi, kad ekspertai ataskaitose rekomenduoja suteikti daugiau galimybiu studentams rinktis ivairias savarankiško darbo formas, o kai kuriose studijų programose neapibūdinti studentų savarankiško darbo metodai.

Ne visose studijų programose ir jų vertinimo ataskaitose galima jžvelgti, kokia savarankiško darbo, nurodomų metodų dermé su dalyko rezultatais ir atitinkamai su programos studiju rezultatais. Studiju programose, kur buvo nurodoma minima dermè, - dažnai savarankiško darbo užduotys, metodai, - nebuvo suderinti arba kilo abejonių dèl dermès su dalyko ir programos rezultatais bei kitomis dalyko aprašo dalimis. Ši pastaba viena rimčiausiuc, nes susijusi su studiju turinio planavimo logikos pažeidimu ir iš to kylančiu galimai nepakankamai efektyviu studijų procesu. Taip pat, remiantis K. Pukelio ir kolegų (2011) pastebejjimais, svarbu studijų rezultatais paremtas požiūris, kai „pagrindinis dèmesys skiriamas studijų rezultatams, kurie pasirenkami atskaitos tašku inicijuojant bei organizuojant studentų savarankišką studijavimą bei vertinant jo metu igytus pasiekimus" (2011, p. 11). Jei studijų programos ar dalyko rezultatas yra susijęs su projektavimo, modeliavimo mokèjimu igijimu, numatytas klasikinis referuojamasis referatas nèra tinkamas pasirinkimas. Taip pat kyla klausimas, kokių analizavimo mokejjimų igys studentas, jei studijų procese, studentų savarankiškame darbe nèra numatyta atvejo analizė ar and portfolio, student presentations (Pukelis et al., 2011). Individuals who renew study programmes should also discuss if a widely used paper (assuming it is a traditional referencing paper) should be changed to a scientific paper or other types of paper that better correspond to the content of bachelor and master study programmes. Augaitienè et al. (2012) noted that independent work should be perceived as multi-dimensional independent learner's activity. Grecevičius (2011) analysed interim reports of renewed study programmes and noted that experts recommend providing students with more diverse possibilities to choose forms of independent work. Students' independent work methods are not described in several study programmes.

Not all study programmes and their assessment reports clearly identify coherence across independent work and its methods and outcomes at subject and programme levels. Those study programmes where this coherence was presented (usually independent work tasks and methods) did not coordinate or poorly coordinated coherence across learning outcomes at subject and programme levels and other sections of subject description. This is one of the most serious issues as it is related to violation of the logic of curriculum planning and, as a result, possibly insufficiently effective study process. Besides, according to Pukelis et al. (2011), learning outcomes based approach is important when "attention is drawn to learning outcomes that are used as a reference point for initiating and organising independent studying, as well as assessing its achievements" (2011, p. 11). If learning outcomes at programme or course unit levels are related to acquisition of designing and modelling skills, the intended referencing paper is not the most appropriate selection. A question is also raised what analysing skills a student will gain if case analysis is not indicated in the study process and students' independent work 
kitaip sudaromos sąlygos ugdytis analizavimo mokèjimus?

Svarbu pastebèti, kad tik trijose studiju programose (iš 24) pateikti studentų savarankiško darbo vertinimo kriterijai. Jei studentams studijų procese nebus pateikiami jų atliekamos veiklos vertinimo kriterijai, nebus atliepiamos elementarios metodinès rekomendacijos, skirtos studentu studijavimo pasiekimų vertinimo procesui tobulinti (taikyti įvairius vertinimo metodus, tinkamus dalyko rezultatų pasiekimui įvertinti, aiškią vertinimo metodiką, supažindinti studentus su jų veiklos vertinimo kriterijais iki atliekant veiklą). Nenurodžius savarankiško darbo vertinimo kriterijų savaime kyla ir studentu studijavimo pasiekimų vertinimo problemų, nesudaromos sąlygos metodiškai organizuojamam studijų procesui. K. Pukelis ir kolegos (2011), apibendrindami mokslininku pastebejimus (Gibbons, 2004; Brookfield, 1985; Hiemstra, 1998; ir kt.) akcentuoja: studentų savarankiško darbo užduotis bei vertinimo kriterijai turètų būti pristatomi kuo anksčiau, pateikiami detaliai ir aiškiai tam skirtoje atmintinèje. Kyla klausimas, kodèl tik keliose studiju programų aprašuose nurodyti studentu savarankiško darbo vertinimo kriterijai? Ar aukštosiose mokyklose nepakankamai metodiškai planuojamas studentų savarankiškas darbas? Studentų savarankiško darbo vertinimo kriterijų skelbimą studentams pagrindžia mokslinè edukologinè literatūra, tačiau Studijų kokybès vertinimo centro direktoriaus isakyme dèl ketinamos vykdyti studijų programos aprašo rengimo, jos išorinio vertinimo ir akreditavimo metodikos patvirtinimo $(2011 \mathrm{~m}$. lapkričio $28 \mathrm{~d}$. Nr. 1-01-157) 20 punkte nurodoma, kad turi būti tik pateikiamas „...programos numatomų studijų rezultatų, mokymo(si) ir studijų pasiekimų vertinimo metodų ryšys...." Šio dokumento 11.2 punkte teigiama: „suteikti informaciją studentams apie tai, ką jie privalès žinoti, gebèti, suprasti baigus programą or no other possibilities to develop analytic skills are provided.

It is important to note that students' independent work assessment criteria are only provided in three study programmes (out of 24). If students are not provided with their activity assessment criteria in the study process, no basic methodological recommendations are reflected that could be used to improve the assessment process of students' learning achievements (i.e. to use various assessment methods, suitable for evaluation of learning outcome achievement at subject level, apply clear assessment methodology, introduce students to activity assessment criteria prior to the beginning of that activity). If no criteria for independent work assessment are provided, issues arise when assessing students' learning achievements and no conditions for methodical organisation of the study process are set. Pukelis et al. (2011) summarised scientists' ideas (Gibbons, 2004; Brookfield, 1985; Hiemstra, 1998; etc.) and emphasised that students' independent work tasks and assessment criteria should be introduced as soon as possible and provided in special detailed guidelines. A question is raised why assessment criteria for students' independent work are only provided in the descriptions of some study programmes. Is students' independent work at higher education institutions planned insufficiently from the methodical perspective? Publication of students' independent work assessment criteria is validated by scientific education literature. However, Section 20 of the order of the Director of the Centre for Quality Assessment in Higher Education On the Approval of the Methodology for the Preparation of the Description, External Review and Accreditation of New Study Programmes (28th of November, 2011, No. 1-01-157) indicates that “...only links between intended learning outcomes and learning outcomes assessment methods..." should be provided. Section 11.2 of this document notes: "to provide information 
(studijų dalyką), kokie bus ju pasiekimu vertinimo kriterijai, metodai, formos. Atnaujintos ketinamos vykdyti studijų programos aprašo rengimo, išorinio jos vertinimo ir akreditavimo metodikos (2013), 22.1 punkte išliko nurodymas dalyku aprašuose pateikti, kokie yra „...tikslai, programos studijų rezultatų, studijų dalyko (modulio) rezultatų, studijų metodų ir studentų pasiekimų vertinimo metodų sąsajos ..., vertinimo kriterijai, studijų dalyko (modulio) turinys, pagrindinè literatūra..." (Studiju kokybès vertinimo centro direktoriaus įsakymas Dèl $\langle\ldots\rangle, 2013)$. Tačiau kitame dokumente aiškiai ịvardijama studentų savarankiško darbo vertinimo kriterijų būtinybe Programos igyvendinimo metu vertinant atnaujintas studiju programas: ,...ivvardinti studento savarankiško darbo metodai ir (arba) užduotys, susiejant su numatomais studijų dalyko ir (arba) modulio rezultatais bei jų vertinimo metodais ir kriterijais..." (Žmogiškųjų išteklių veiksmų programos 2 prioriteto „Mokymasis visą gyvenimą" $<\ldots$,. 2010). ŠMM internetiniame puslapyje publikuojamų rekomendacijų studijų rezultatų vertinimui tobulinti (2009) 10 punkte nurodoma: „semestro pradžioje desstytojas turi informuoti studentus apie aukštosios mokyklos studijų rezultatų vertinimo tvarką išdèstydamas detalią dalyko programą, tikslus, laukiamus studijų rezultatus, konkrečią dėstomojo dalyko studijų rezultatų vertinimo struktūrą (tarpinių atsiskaitymų ittaką galutiniam pažymiui, kokiems rezultatams esant teks kartoti dalyko kursą arba bus galima pakartoti galutini atsiskaitymą), vertinimo kriterijus ir reikalavimus“. Pastebimas prieštaravimas tarp nacionalinių dokumentų, rekomendacijų, reglamentuojančių studijų programas, ir Žmogiškujjų išteklių veiksmų programos 2 prioriteto „Mokymasis visą gyvenimą" VP12.2-ŠMM-07-K „Studijų kokybės gerinimas, tarptautiškumo didinimas", atnaujinamų studijų programų tarpiniovertinimo reikalavimų. Todèl pristatyti tikrąją situaciją apie studentų to students on what they must know, be able to do and understand upon completion of a study programme (subject) and what their achievement assessment criteria, methods and forms will be". Section 22.1 of the Methodology for the Preparation of the Description, External Review and Accreditation of Renewed Study Programmes (2013) indicates the need for descriptions of course units to provide "... aims, links among learning outcomes at programme level and subject (module) level and student achievement assessment methods..., assessment criteria, content of subject (module), essential literature..." (Studijų kokybès vertinimo centro direktoriaus įsakymas Dèl $<\ldots>$, 2013). However, another document clearly indicates the need to present students' independent work assessment criteria when assessing renewed study programmes during the Programme implementation period: “...student's independent work methods and (or) tasks are identified, relating them to intended learning outcomes at course unit and (or) module level and their assessment methods and criteria..." (Žmogiškujų išteklių veiksmų programos 2 prioriteto „Mokymasis visą gyvenimą" <...>, 2010). Section 10 of the recommendations on the improvement of learning outcome achievement assessment (2009) published on the website of the Ministry of Education and Science states: "at the beginning of the term a teacher should inform students about the order of learning outcome achievement assessment set by a higher education institution, involving a detailed description of a subject programme, aims, intended learning outcomes, a specific structure for the assessment of learning outcomes at subject level (the influence of mid-term on the final grade, what grades will require a student to repeat the course and whether they will be able to retake a final exam), assessment criteria and requirements". Contradictions have been noted in national documents, recommendations that regulate study programmes and requirements 
savarankiško darbo vertinimo procesą, ar ivardijami savarankiško darbo kriterijai, kaip su jais supažindinami studentai, kiek jie yra aiškūs ir metodiškai parengti, būtų galima atlikus išsamesnius tyrimus. Taip pat keliamas diskusinis klausimas: ar tikslinga studijų programos apraše, dalykų programose pateikti studentų savarankiško darbo vertinimo kriterijus, gal tai turètų būti studijų programos priedų dalis? Dėstytojai ịvairiai organizuoja studijų procesą, dalis pateikia kompleksą savarankiško darbo užduočių, kiti - vieną ar kelias sudètingas, kompleksines. Tačiau informacija apie savarankiško darbo vertinimo strategiją, vertinimo kriterijus studentams turètų būti laisvai pasiekiama dar kurso dèstymo pradžioje. Tai aktualu siekiant atliepti mokslinejje literatūroje išskirtą vertinimo paskirtị: diagnozavimo, formavimo, sumavimo ir išorinio ivertinimo (Weeden, Winter, Broadfoot, 2005). G. Petty (2006) pažymi kriterinio vertinimo svarbą ir poreiki taikyti kriterijus, kad būtu galima pamatuoti, ką besimokantysis moka daryti, o ko ne.

Beveik trečdalyje (7 iš 24) studijų programų prie dalyko programų buvo pateikti savarankiško darbo planai, kuriuose nurodyta: savarankiško darbo užduoties pavadinimas, metodai, užduočių skaičius, rekomenduojamas savarankiško darbo laikas, užduoties įtaka galutiniam pažymiui (procentais). Dalykų programose savarankiško darbo užduočių aprašo išsamumas, metodinis pagrindimas labai skyrèsi: nuo išsamių, pasižyminčių puikiu metodiniu pagrindimu, iki abstrakčių, lakoniškų aprašų. A. Rauckienè (2011) pastebejjo, kad peržiūrètose atnaujinamų programų ataskaitose savarankiško darbo turinys buvo neaiškus. Apibendrindamas studijų programų atnaujinimą, L. Leonas (2011) taip pat išskyrė problemas, susijusias su studentų savarankiško darbo planavimu: nenurodytos savarankiško darbo formos, metodai ir vertinimo metodai, kriterijai arba pateikta tik bendra savarankiško darbo apimtis, todèl neaišku, ką for interim assessment of renewed study programmes that were formulated under the Operational Programme for the Development of Human Resources 2007-2013 2nd Priority "Life-long Learning" VP1-2.2- MM-07-K measure "Enhancing of the Quality of Studies, Strengthening of Internationality". Therefore more comprehensive research is required to reveal real situation about the students' independent work assessment process and to find out if independent work criteria are identified, how they are presented to students, whether they are clear and methodically prepared. A question is also raised if students' independent work assessment criteria should be provided in the study programme or course unit descriptions? Maybe it would be better to involve them in the annexes of study programme descriptions? The ways teachers organise the process of studies varies, i.e. some of them provide a complex of independent work tasks while others prefer one or several difficult, complex tasks. However, information about the strategy of independent work assessment and assessment criteria should be provided to students at the beginning of a course unit. All this helps to reflect assessment aims presented in scientific literature: diagnostic, formative, summative and external assessment (Weeden, Winter, Broadfoot, 2005). Petty (2006) emphasises the importance of criteria-based assessment and the need to apply criteria in order to measure what a learner can and cannot do.

Almost a third (7 out of 24) of study programmes provided independent work plans next to course unit programmes. They involved: title of an independent work task, methods, number of tasks, recommended independent work time, the influence of a task on the final grade (percentage). Comprehensiveness and methodical validation of independent work descriptions in course unit programmes differed from comprehensive and methodically validated to abstract, general descriptions. Rauckiene (2011) noted that the 
studentas turi daryti, kokio pobūdžio užduotis jam skirta; autoriaus pastebejimu, nurodoma pagrindinè literatūra, tiksliau, jos kiekis, niekaip nesuderinti su studentų galimybèmis. Analizuojant studijų programas (aptariamas vienas trečdalis iš analizuotų, nes tik jose pateikta informacija) taip pat kilo abejonių, ar dèstytojai, planuodami savarankišką studentų darbą, atsižvelgia į dalyko kreditų skaičių? Anot R. Bartkevičiaus ir kolegų (2013), ši problema aktuali ir $2013 \mathrm{~m}$. vertintoms studiju programoms. T.Bulajevos (2011) nuomone, pereinant prie studijų, orientuotų i studentą, būtina daugiau dèmesio skirti studentu mokymosi veiklos planavimui, organizavimui ir studento darbo krūvio bei studijų laiko apskaitai. Pastebèta, kad kai kurios aukštosios mokyklos, kurių studijų programas vertino ekspertai (iš vertintų studijų programų būdinga tik nevalstybinėms kolegijoms), ì dalyko aprašą ịtraukẻ laiko savaitèmis nuorodą, kada atlikti ir pateikti savarankiško darbo užduotį. Aukštojoje mokykloje derinant ịvairių dalykų savarankiškų darbų atlikimo planą, studentų laikas skirstomas racionaliai ir sudaromos palankios sąlygos kokybiškai, planingai atlikti savarankiško darbo užduotis. Todèl tikslinga skatinti dèstytojus kolegiškai aptarti ir realiai ịvertinti studentui reikalingą laiką užduočiai atlikti ir numatytas valandas dalyko apraše. content of independent work in the reports of renewed study programmes was unclear. Leonas' (2011) generalisations of study programme renewal identified problems related to independent work planning: forms, methods and assessment methods for independent work are not provided or only general volume of independent work is provided; thus it is not clear what a student should do and what kind of task s/he will be given. The author also notes that the amount of provided literature resources exceeds students' possibilities. The analysis of study programmes (a third of them are discussed as only they provide information) has also raised doubts if teachers take into account the number of subject credits when planning independent work. According to Bartkevičius et al. (2013) this problem is also relevant in study programmes assessed in 2013. Bulajeva (2011) notes that the transfer to studentcentred studies should focus on planning and organising students' learning activity as well as on records of student workload and learning time. Several higher education institutions that were assessed by experts (only noticed in the assessed non-governmental colleges) provided course unit descriptions with a reference to weeks, i.e. when an independent work task should be performed and presented. When coordinating schedules of various independent work tasks, a higher education institution should distribute students' time rationally and enable students to perform their tasks in highquality and as planned. Thus teachers should be encouraged to talk to their colleagues and realistically evaluate hours given in the course unit descriptions and how much time a student will need to complete their task. 


\section{STUDIJU PROGRAMAS}

ATNAUJINUSIŲ ASMENŲ IৃARDYTOS PROBLEMOS, TRŪKUMAI, PLANUOJANT STUDENTŲ

SAVARANKIŠKĄ DARBĄ PAGAL PROGRAMĄ ATNAUJINAMOSE STUDIJŲ PROGRAMOSE

Per pokalbius su studijų programas atnaujinančiais asmenimis išaiškejjo, kad vykusių informacinių seminarų metu nebuvo suteikta pakankamai informacijos, kaip ir ką reikia pateikti apie studentų savarankišką darbą. Todèl priimdami sprendimus, kaip studijų programose aprašyti savarankišką darbą, jie rèmèsi vykdomo projekto paraiška žiūrèdami, ar studentų savarankiškas darbas, kaip atnaujinimo sritis, numatytas aukštosios mokyklos vykdomame projekte. Dalis studijų programas atnaujinančių asmenų pripažino koncentravęsi î, jų požiūriu, aktualesnius aspektus (pvz., it studijų programos rezultatų atnaujinimą, atitikmeni atnaujintiems nacionaliniams aktams, europinèms rekomendacijoms dèl studijų turinio) nei studentų savarankiško darbo organizavimo atnaujinimas ir aprašymas.

Išaiškèjo, kad buvo neaišku, ne tik kaip ir kiek išsamiai aprašyti atnaujinamas programas, bet ir kurioje studiju programos dalyje pateikti informaciją apie studentų savarankišką darbą. Ar studijų programos bendrajame apraše, ar dalyko aprašuose, ar individualiuose dèstytojo teminiuose planuose? Studijų programas atnaujinantys asmenys pažymėjo, kad rekomenduojamoje dalyko aprašo formoje (remiantis Studijų kokybès vertinimo centro direktoriaus patvirtinta rekomenduojama forma dalyko aprašui) nèra vietos savarankiškam darbui, jo vertinimo kriterijams. Tik nedaugelio aukštụjų mokyklų atstovai èmèsi iniciatyvos rekomenduojamą, Studijų kokybès vertinimo centro direktoriaus patvirtintą, dalyko aprašo formą papildyti

\section{STUDENTS' INDEPENDENT WORK PLANNING ISSUES IN STUDY PROGRAMMES RENEWED UNDER THE PROGRAMME, AS PRESENTED BY INDIVIDUALS WHO RENEWED STUDY PROGRAMMES}

Interviews with people who renew study programmes have revealed that informative seminars did not provide sufficient information about what and how should be provided about students' independent work. Thus when making decisions on how to describe independent work in study programmes they analysed if students' independent work as one of renewable areas is involved in the project performed by a higher education institution. A part of individuals who renew study programmes said that they focused on the aspects that they believe are more important (e.g. renewal of learning outcomes at study programme level, correspondence to renewed national acts, European recommendations on curriculum) than renewal and descriptions of students' independent work organisation.

It was not clear not only how and how thoroughly renewed study programmes should be described but also in which section of a study programme information regarding students' independent work should be provided, i.e. in a general description of a study programme or descriptions of course units or individual teacher's plans? Individuals who renewed study programmes noted that the recommended form for course unit description (as approved by the director of the Centre for Quality Assessment in Higher Education) does not have a section for independent work and its assessment criteria. Only a few representatives of higher education institutions took initiative to supplement the recommended form of course unit description, approved by the director of the Centre for Quality Assessment in Higher 
dalimis, skirtomis studentu planuojamam savarankiškam darbui išsamiau atskleisti ar su dalyko aprašu pateikti priedą, kuriame aprašoma, kaip ketinama organizuoti studentu savarankišką darbą. Dalyko aprašo forma yra rekomendacinio pobūdžio ir papildomos korekcijos galimos - tai turètų būti aukštosios mokyklos iniciatyva siekiant aiškaus, kokybiško studentu savarankiško darbo.

Beveik visi pokalbyje dalyvavę studijų programas atnaujinę asmenys negalejo metodiškai įvardyti, kaip užtikrinti savarankiško darbo sąsajas su dalyko rezultatais. Remiantis studiju programos projektavimo metodologinèmis nuostatomis, nacionaliniais teisès aktais, reglamentuojančiais studijų programos rengimą, studentų savarankiškas darbas turètų sudaryti sąlygas igyti, įtvirtinti, tobulinti žinias, mokejjimus, itvardijamus dalykų ir studiju programos rezultatuose. Taip pat studentams turètų būti suteikiamos galimybès pasirinkti ivairias savarankiško darbo užduotis, metodus, formas, padedančias pasiekti numatytą, atitinkamą tą pati dalyko rezultatą. Savarankiškas studentų darbas turi būti planuojamas apibrèžiant, ịvardijant tikslus, keliamus reikalavimus, numatant užduoties įsivertinimo ir įvertinimo kriterijus, įvertinant laiką, per kurị galima atlikti užduotị, bendrą savarankiško darbo užduočių skaičių ir jų dermę su dalyko programa bei apimtimi. Paaiškejo, kad dauguma studijų programas atnaujinančių asmenų, dalyvavusių pokalbyje, savarankišką darbą planuoja turèdami viziją, ką studentas būtinai turi gebèti atlikti studijuodamas pagal dalyko programą. Kai kurie savarankišką darbą sieja su tuo, ko nespejama, negalima atlikti kontaktinio darbo su studentais metu. Dalis studiju programas atnaujinančiu asmenu, planuodami savarankišką studentų darbą, nesiejo jo su dalyko rezultatais, tik paskui paanalizavę atrado intuityvių sąsajų. Nesieti savarankiško darbo su dalyko ir studijų programos rezultatais - ydinga praktika, nes tampa neaiški
Education, with sections aimed at presenting planned students' independent work or to provide an annex where plans for organising students' independent work are described. A form of course unit description is of recommendable nature thus further corrections are allowed. It should be done under initiative of a higher education institution with the aim of clear and high-quality students' independent work.

Almost none of the interviewed individuals who renewed study programmes could methodically explain how to assure that independent work was linked to learning outcomes. On the basis of methodological provisions for study programme design and national legal acts that regulate study programme designing, students' independent work should enable them to acquire new knowledge and skills identified in learning outcomes at programme and course unit level. Students should also be able to choose form a variety of tasks, methods and forms of independent work that enable to achieve formulated learning outcomes. Students' independent work should be planned by defining and presenting aims and requirements, setting criteria for task (self)evaluation, evaluating time given to complete a task, overall number of independent work tasks and how they match the programme and volume of a course unit. The majority of interviewed individuals who renew study programmes plan independent work in accordance with what a student must be able to do when studying a particular course unit. Some of them associate independent work with things that are not or cannot be completed during contact hours. Several individuals who renew study programmes noted that when planning independent work they did not coordinate it to learning outcomes and only later found certain intuitive links. However, not coordinating independent work to learning outcomes at programme level is a faulty practice as its purpose becomes unclear. Besides planners often 
jo paskirtis. Be to, planuotojams dažnai kilo klausimų, kiek savarankiškų darbų planuoti, ar kiekvienam dalyko rezultatui būtinai reikalingas savarankiškas darbas. Studentų savarankiško darbo kiekis, apimtis, turinys priklauso nuo to, kokių siekiama dalyko rezultatu, kokia dalyko apimtis kreditais, kiek valandų skirta savarankiškam darbui, ir kitų susijusių studijų proceso dalių. Nèra būtinybès, poreikio kiekvienam dalyko rezultatui planuoti savarankišką darbą, galima numatyti kompleksini savarankišką darbą, padedanti pasiekti kelis dalyko rezultatus. Bet labai svarbu pateikti studentams išsamią metodinę informaciją apie savarankiško darbo paskirtį, turinị, atlikimą, vertinimą, sudarančią sąlygas efektyviai veiklai. Todèl, siekiant aiškaus studijų proceso, dèstytojui svarbu organizuoti konsultacijas studentams. K. Pukelis ir kolegos (2011) pastebi, kad studentų konsultacijos galètų vykti šiomis kryptinis: savarankiško darbo temos pasirinkimas ir suderinimas; savarankiško darbo plano aptarimas; informacijos šaltinių aptarimas; savarankiško darbo rezultatų aptarimas; savarankiško darbo apibendrinimas ir išvadų formulavimas; savarankiško darbo pristatymo aptarimas.

Studijų programas atnaujinantys asmenys teigè: neturint edukologinio išsilavinimo, nepakankamai aišku, kokie inovatyvūs savarankiško darbo metodai, kur pateikiamas jų sąrašas. IT technologijų integravimas i studijų procesą sudaro puikias sąlygas studentų savarankiško darbo inovatyvumui. Moodle sistemoje ar kitoje elektroninio mokymosi platformoje studentams gali būti pateiktos ìvairios užduotys (individualios ir grupinès), leistina ugdyti mokejimus, įsivertinti pasiekimus. Tikslingai parinkus studentų savarankiško darbo metodus pagal siekiamus aktualius dalyko rezultatus, dalyku turini bei inovacijų taikymas sudaro palankias sąlygas sèkmingam studijų procesui. Dėstytojui nepakanka parinkti inovatyvių ar populiarių savarankiško darbo metodų, svarbu jų faced questions how many independent work tasks to plan and whether a separate independent work task is required for each learning outcome? The amount, volume and content of students' independent work depend on what learning outcomes are set for a course unit, what number of credits a course unit has, how many hours are given to independent work and other related aspects. It is not necessary to plan a separate independent work for every learning outcome. Students can be given a complex independent work that helps to achieve several learning outcomes. However it is very important to provide students with comprehensive methodological information regarding the purpose, content, completion and assessment of independent work that enables students to act effectively. Therefore in order to achieve a clear study process, teachers should organise consultations to their students. Pukelis et al. (2011) note that the following types of consultations could be organised: choosing and coordinating the theme of independent work; discussing the plan of independent work; discussing information resources; discussing outcomes of independent work; generalising independent work and making conclusion; discussing independent work presentation.

Individuals who renew study programmes claim that unless you have background in education, it is not clear what innovative independent work methods are and where their list is provided. Integration of IT technologies into the study process is a perfect way to ensure innovative independent work. Various tasks (individual or group) that enable developing skills and self-assessing achievements can be given to students in the Moodle system or any other e-learning platform. Successful study process can be achieved by choosing appropriate independent work methods that focus on relevant learning outcomes and content and by introducing innovations. It is important for a teacher to not only choose innovative or popular independent work methods but also 
dermé su studijų turiniu. Reikètų sudaryti sąlygas studentui rinktis metodus, labiausiai atliepiančius individualius poreikius, siekiant tikslingame studijų procese numatytų dalyko rezultatų. Aukštosiose mokyklose gali būti taikomi įvairūs studentų savarankiško darbo metodai: mokslinès literatūros apžvalga, mokslinè chronologinè analizé, esé, recenzija, ìvairių mokslo darbų kritinis vertinimas, Venno diagramos ${ }^{3}$, apžvalgos, ịvairaus tipo referatai, kūrybiniai darbai, mokymosi dienoraščiai ir įvairūs reflektavimai, praktinių duomenų rinkimo ataskaitos, atvejo analizé, projektai, aplankas (portfolio), pranešimai ar studentu prezentacijos bei kiti metodai.

Dèstytojai, studijų programas atnaujinę asmenys, neišskyrẻ kilusių problemų, susijusių su studentų savarankiško darbo vertinimu, bet kalbantis paaiškejjo, kad ne visi dèstytojai viešina ar turi parengę savarankiško darbo vertinimo kriterijus; kai kurių manymu, pakanka informacijos, kokią kaupiamojo balo procentinę dalị sudaro studentų savarankiškas darbas. Siekiant aiškumo, studentų studijavimo pasiekimų vertinimo objektyvumo, rekomenduojama atkreipti dèmesi i kriterijų sampratą. ${ }^{4}$ Dažniausiai kriterijai susiję su atitinkamos studijuojamo dalyko / modulio pakopos ir (arba) lygio aprašais, kurie pateikiami studentams studijuc programos kataloguose ar kituose dokumentuose kartu su studiju rezultatais, kurso programa ir pan. (Tuning: Europos švietimo struktūrų suderinimas, 2010). Atnaujinant studijų programas, rekomenduojama parengti aiškius studentu studijavimo pasiekimų vertinimo kriterijus aprašus, ką studentas turi mokèti padaryti ar

3 Venno diagrama susideda iš ne mažiau kaip dvieju susikertančių arba esančių vienas kitame apskritimų, pagal kuriuos galima išskirti objektų panašumus ir skirtumus, taip pat tinka iliustruoti loginius arba matematinius ryšius tarp skirtingų objektų ar grupių

4 Kriterijus (gr. kriterion - matas, vertinimo pagrindas) požymis, pagal kurị kas nors vertinama, nustatoma, klasifikuojama; vertinimo pagrindas, matas, saikas (Tarptautinių žodžių žodynas, 2001); sprendimo vertinimo pagrindas, matas (Dabartinès lietuvių kalbos žodynas, 2000). to coordinate them to the curriculum. In order to achieve learning outcomes set in the study process, a student should be given a possibility to select such methods that help to reflect individual needs. Higher education institutions can use various students' independent work methods: scientific literature review, scientific chronological analysis, essay, reviews, critical assessment of various scientific works, Venno diagrams ${ }^{9}$, papers, creative works, learning diaries and reflections, reports on practical data collection, case analysis, projects, portfolio or student presentations and other methods.

Teachers, individuals who renewed study programmes did not identify problems related to students' independent work assessment. However, interviews have revealed that not all teachers publish or even have independent work assessment criteria. Some of them believe that it is sufficient to provide information on what part (percentage) of cumulative score consists of student's independent work. To achieve accuracy and objective assessment of students' learning achievements, attention should be drawn to the concept of criteria. ${ }^{10}$ Criteria are usually related to descriptions of specific course unit / module cycle and (or) level that together with learning outcomes, course programme etc. are provided to students in study programme catalogues or other documents (Tuning: Europos švietimo struktūrų suderinimas, 2010). When renewing study programmes, it is recommended to prepare accurate criteria-descriptions for the assessment of student learning achievements. They should involve information on what a student should be able to do or provide in order to demonstrate the level of achieved learning

9 Venn diagram consists of no less than two intersecting circles and can be used for presenting object similarities and differences, as well as for illustrating logical or mathematical relations among different objects or groups.

10 Criterion (gr. kriterion - measure, base for assessment) an attribute against which something is assessed, identified, classified; base, measure for assessment (Tarptautiniu žodžių žodynas, 2001); base, measure for assessing decisions. (Dabartinès lietuvių kalbos žodynas, 2000). 
pateikti, kad pademonstruotų, kokiu lygiu yra pasiekęs numatytus studijų rezultatus, ar išsamiau apibūdinti vertinimo skalès taikymą. Aiškūs kriterijai suponuoja konstruktyvų grị̌žtamąji ryši ir ugdomąji vertinimą. Vertinimas turi būti paremtas įrodymais (rodikliais), todèl svarbūs ir vertinimo rodikliai. Tai plačiau nei tradicinis apibendrinamasis vertinimas, nes leidžia padaryti studijuojančiųjų pažangos „fotografiją“ (Assessment is for Learning, 2006).

\section{IŠVADOS}

1. Pagal 2007-2013 m. Žmogiškųjų išteklių plètros veiksmų programos 2 prioritetą „Mokymasis visą gyvenimą" atnaujinant studijų programas, problemų kilo dèl savarankiško darbo metodų, užduočių ìvairovès, suderinamumo su dalyko rezultatais, dalyko programa, apimtimi kreditais bei studentų savarankiško darbo vertinimo.

2. Ekspertai pastebejo, kad tik nedaugelis studijų programų dalykų aprašų rengèjų atliepé tiek nacionalines, tiek europines rekomendacijas, susijusias su studentų studijavimo pasiekimų vertinimo proceso tobulinimu, tik 3 iš 24 studijų programų buvo pateikti studentų savarankiško darbo vertinimo kriterijai. Tačiau taip nutikti galèjo dèl nepakankamos dermès tarp reglamentuojančių studijų programų atnaujinimą nacionalinių teisès aktų ir dalies šių teisès aktų turinio prieštaringumo. Todèl spręsti, kaip realiai organizuojamas studentų savarankiškas darbas, galima tik atlikus išsamesnius tyrimus aukštosiose mokyklose.

3. Vienas rimčiausių trūkumų - studijų programose numatyto studentų savarankiško darbo nepakankama dermė su studijų dalyko ir programos rezultatais. Tai susiję su studijų turinio projektavimo outcomes or should provide a more explicit description of the assessment scale. Clear criteria suppose constructive feedback and educational assessment. Assessment should be based on evidence (indicators); thus, attention is also drawn to assessment indicators. This assessment is broader than traditional generalising assessment as it allows making a "photograph" of students' progress (Assessment is for Learning, 2006).

\section{CONCLUSION}

1. Problems faced when renewing study programmes under the Human Resources Development Action Programme 2007-2013 priority direction 2 "Lifelong Learning" are related to the methods of independent work, the variety of tasks, compatibility with learning outcomes at subject level, its content, volume in credits and assessment of students' independent work.

2. Experts noted that only a few developers of study programme course unit descriptions took into account both national and European recommendations related to the improvement of the process of learning achievement assessment. Only 3 out of 24 programmes had students' independent work assessment criteria. However this could have happened due to insufficient coherence across national legal acts that regulate study programme renewal and contradictions in the content of some of these acts. Thus more comprehensive research is required to reveal real situation about students' independent work organisation.

3. One of key disadvantages - insufficient coherence across students' independent work planned in study programmes and learning outcomes at programme and subject levels. This could be related 
logikos pažeidimu, galimai nepakankamai efektyviu studijų procesu ir grèsme, kad studentas nepasieks ar nepakankamai kokybiškai pasieks numatytus dalyko ir studijų programos rezultatus.

4. Viena sunkiausių veiklų studijų programas atnaujinantiems asmenims - metodiškai ìvardyti, kaip užtikrinti savarankiško darbo sąsajas su dalyko rezultatais, studijų programos rezultatais, bei parinkti inovatyvius, tikslingus savarankiško darbo metodus.

\section{REKOMENDACIJOS}

1. Planuojant studentu savarankišką darbą, rekomenduojama iš anksto nurodyti savarankiško darbo indèli siekiant dalyko ir studijų programos rezultatų bei pateikti išsamią metodinę informaciją apie savarankiško darbo paskirtị, turini, atlikimo terminus, vertinimo kriterijus ir metodus, organizuoti konsultacijas studentams.

2. Rekomenduojama studentams sudaryti galimybes savarankiško darbo užduotis atlikti ìvairiais metodais, tinkamais tikslingai pasiekti dalyko, studijų programos rezultatus, derančius su studiju turiniu ir procesu bei labiausiai atliepiančius individualius poreikius. to breaching logic when designing curriculum, insufficiently effective process of studies and the threat that a student will not achieve or will insufficiently achieve learning outcomes set at programme and course unit levels.

4. One of most difficult activities identified by individuals who renewed study programmes was to methodically identify how to assure links between independent work and learning outcomes at course unit and study programme levels and choose innovative and purposeful independent work methods.

\section{RECOMMENDATIONS}

1. When planning students' independent work, it is recommended to identify in advance the input of independent work in learning outcomes at course unit and programme levels and to provide explicit methodical information on the purpose, content, deadlines, assessment criteria and methods of independent work, as well as to organise consultations to students.

2. It is recommended to enable students to perform their independent work in a variety of methods that allow achieving learning outcomes at course unit and programme levels, are compatible with curriculum and study process and reflect individual needs.

\section{LITERATŪRA / REFERENCES}

Augaitienè R., Augutienè E., Bučelienè J. (2012). Studentu savarankiško darbo itakos matematikos dalyko mokymuisi tyrimas. Profesines studijos: teorija ir praktika, 9, p. 18-25. Šiauliai: ŠVK

Assessment is for Learning. Self-Assessment Toolkit. Scotland, 2006.
Atnaujinamu studiju programu tarpinio vertinimo ataskaitos gaires (2011). MOSTOS parengtos rekomendacijos atnaujinamu studiju programu tarpinio vertinimo eksper tams [rankraštis].

Bartkevičius R. ir kt. (2013). Studiju programy atnaujinimo rezultatai. Švietimo ir mokslo ministerijos užsakymu parengta informacinè medžiaga aukštosioms mokykloms [rankraštis]. 
Bamberger M. (2000). The evaluation of international development programs: a view from the front. The American Journal of evaluation, 21 (1), Winter, p. 95-102.

BOLOGNA beyond 2010. Report on the development of the European Higher Education Area (2010). Internetinis adresas: http://www.ehea.info/Uploads/Irina/Bologna\%20beyond\%202010.pdf. Puslapis aplankytas $2013 \mathrm{~m}$. kovo $1 \mathrm{~d}$.

Budrienė A., Margelienė J. (2010). Integruoto savarankiško darbo taikymas studiju procese: Kauno kolegijos kraštotvarkos fakulteto patirtis. Internetinis adresas: http:// www.viko.lt/uploads/files/2010/Straipsniai/04\%20straipsnis. pdf. Puslapis aplankytas: $2013 \mathrm{~m}$. kovo $1 \mathrm{~d}$.

Bulajeva T. ir kt. (2011). Studijų programų atnaujinimas: kompetencijų plètotès ir studijų siekinių vertinimo metodika. Internetinis adresas: http://www.ects.cr.vu.lt/Projekto_ rezultatai. Puslapis aplankytas: $2011 \mathrm{~m}$. rugsejo $8 \mathrm{~d}$.

Čiapukas R. (2005). Socialinių pedagogų neuniversitetinio rengimo tendencijos ir ju ivvertinimas Lietuvoje. Klaipeda: Klaipedos universitetas. Nepublikuota edukologijos daktaro disertacija.

Dabartinès lietuviu kalbos žodynas. (2000). 4-asis leid. Lietuvių kalbos institutas. Vilnius: Mokslo ir enciklopedijų leidybos instituto leidykla, $967 \mathrm{p}$.

Grecevičius P. (2011). Atnaujinamų studijų programų tarpinio vertinimo ataskaitu analizè. Internetinis adresas: http://www.smm.lt/es_parama/rm/docs/programu\%20atnaujinimo\%20analize-Grecevicius.pdf. Puslapis aplankytas $2011 \mathrm{~m}$. birželio $6 \mathrm{~d}$.

Jurkšaitienè N. (2010). Kauno kolegijos kraštotvarkos fakulteto želdinių ir agrotechnologijų katedroje rengiamų specialistų savarankiškumo ugdymo ypatumai. Tyrimai šiuolaikinèje visuomenèje, 1, p. 55-60. Kaunas.

Laipsnị suteikiančių pirmosios pakopos ir vientisųjų studijų programų bendrųjų reikalavimų aprašas, patvirtintas LR ŠMM ministro įsakymu Nr. V-501 (Žin., 2010-04-17, Nr. 44-2139; 2010-07-24, Nr. 88-4676; 2011 01-22, Nr. 9-399).

Kerr J. F (ed.). (1967). Changing the curriculum. London: University of London press LTD. Laužackas R. (2000). Mokymo turinio projektavimas. Kaunas: VDU leidykla.

Laužackas R. (2008). Kompetencijomis grindžiamu mokymo/studiju programu kūrimas ir vertinimas. Kaunas: VDU leidykla.

Losak J., Burns N. (1971). An Evaluation of the Community College Studies Program for the Year 1969-70. Internetinis adresas: http://search.epnet.com. Puslapis aplankytas 2004 m. rugpjūčio $8 \mathrm{~d}$.

LR Mokslo ir studiju istatymas (2009). Valstybès žinios, 2009-05-12, Nr.54-2140. Vilnius.

Mayring P. (2000). Qualitative Content Analysis. Forum: Qualitative Social Research, 1 (2). Internetinis adresas: http:// qualitative-research.net/fqs. Puslapis aplankytas $2008 \mathrm{~m}$. balandžio $16 \mathrm{~d}$.
Pečiūrienė A., Radlinskaitė R., Žvinakevičienė D. (2010). Savarankiškas darbas profesinio bakalauro studijų procese. Internetinis adresas: http://www.viko.lt/uploads/ files/2010/Straipsniai/05\%20straipsnis.pdf. Puslapis aplankytas 2013 m. kovo $3 \mathrm{~d}$.

Petty G. (2006). Šiuolaikinis mokymas. Vilnius.

Pukelis K. ir kt. (2011). Savarankiško studijavimo panaudojant e-priemones metodika (Methodics of independent learning using e-learning means, in Lithuanian). Internetinis adresas: http://skc.vdu.lt/downloads/projekto_rezultatai/metodika_taisyta_05-03_maketuota_3.pdf. Puslapis aplankytas $2013 \mathrm{~m}$. kovo $3 \mathrm{~d}$.

Pukelis K. (1999). „Curriculum“ sampratos adaptavimasis lietuviškoje pedagogineje kultūroje: problemos ir siūlymai (Adaptation of concept "curriculum" to Lithuanian pedagogical culture: problems and proposals, in Lithunian). Socialines kaitos procesai ir profesinio rengimo vyksmas. 2 knyga, p. 82-89. Kaunas: VDU leidykla.

Pukelis K., Sajienè L. (2000). Curriculum sampratos problema Lietuvių pedagoginès kultūros kontekste. Pedagogika: mokslo darbai, 40, p. 14-26.

Pukelis K. (2009). Ability, Competency, Learning / Study outcome, Qualification and Competence: Theoretical Dimension // The Quality of Higher education, No. 6, p. 12-35. Kaunas: VDU leidykla.

Pukelis K. (2011). Study Programme designing and Renewal: Learning Outcome Paradigm // The Quality of Higher Education, No. 8, p. 38-73. Kaunas: VDU leidykla.

Pukelis K., Smetona A. (2011). Harmonisation of the Educational Concept "Learnng Outcome" in the Lithuanian Language // The Quality of Higher Education, No. 8, p. 12-37. Kaunas: VDU leidykla.

Rauckienė A. (2011). Socialinių mokslų studijų programų ypatumai. Internetinis adresas: http://www.smm.lt/es_para$\mathrm{ma} / \mathrm{rm} /$ docs/programu\%20atnaujinimo\%20analize-Rauckiene.pdf. Puslapis aplankytas $2011 \mathrm{~m}$. birželio $3 \mathrm{~d}$.

Rossi P. H., Lipsey M. W., Freeman H. E. (2003). Evaluation (7th ed.). Thousand Oaks-London-New Delhi: SAGE Publications.

Royse D., Thyer B. A. (1996). Program evaluation. Chicago: Nelson-Hall Publishers.

Rupšienė L., Mažionienè A. (2011). Savarankiškas darbas aukštojoje mokykloje socialinio pedagogo vadybinių kompetencijų ugdymo požiūriu: studentų nuomonè. Tiltai, 56 (3), p. 151-158. Klaipèda: KU leidykla.

Savickienė I. (2011). Designing of Student Learning Achievement Evaluation // The Quality of Higher Education, No. 8, p. 74-93. Kaunas: VDU leidykla.

Seminaro „Atnaujinamų studijų programų tarpinio vertinimo rezultatai“ medžiaga, 2011. Internetinis adresas: http:// www.smm.lt/es_parama/rm/. Puslapis aplankytas $2011 \mathrm{~m}$. birželio $6 \mathrm{~d}$. 
Studijų programų, atnaujinamų pagal ES struktūrinių fondų projektus, tarpinio vertinimo ekspertai ir konsultantai (2010). Internetinis adresas: http://www.mosta.lt/senas/ Files/Atnaujinamu_studiju_programu_ekspertai7.pdf. Puslapis aplankytas $2011 \mathrm{~m}$. sausio $21 \mathrm{~d}$.

Studijų kokybės vertinimo centro direktoriaus įsakymas Dèl ketinamos vykdyti studijų programos aprašo rengimo, jos išorinio vertinimo ir akreditavimo metodikos patvirtinimo $2011 \mathrm{~m}$. lapkričio $28 \mathrm{~d}$. Nr. 1-01-157. Internetinis adresas: http://www3.lrs.lt/pls/inter3/dokpaieska. showdoc_l?p_id=413149.

Studijų kokybès vertinimo centro direktoriaus ịsakymas Dèl ketinamos vykdyti studijų programos aprašo rengimo, jos išorinio vertinimo ir akreditavimo metodikos, patvirtintos studijų kokybès vertinimo centro direktoriaus $2011 \mathrm{~m}$. lapkričio 28 d. ịsakymu nr. 1-01-157, pakeitimo patvirtinimo $2013 \mathrm{~m}$. balandžio $22 \mathrm{~d}$. Nr. V-23. Valstybės žinios, 201305-11, Nr. 49-2469.

Tarptautinių žodžių žodynas (2001), (red. V. Kvietkauskas ir kt.). Vilnius.

Tyler R. W. (1949). Basic principles of Curriculum and Instruction. Chicago: The University of Chicago Press.

Tuning: Europos švietimo struktūrų suderinimas, (2010). Vilnius.

Žibènienè G. (2006). Neuniversitetiniu studiju programy kokybes vertinimo teorinis ir empirinis pagrindimas. Vilnius: Ciklonas.
Žibėnienė G. (2011). Studijų programų atnaujinimo Lietuvoje apžvalga: studijų programos tikslų, studijų rezultatų formulavimo problematika ir tobulinimo metodiniai aspektai. Pedagogika, 104, p. 79-86. Vilnius: VPU leidykla.

Žmogiškujų išteklių veiksmų programos 2 prioriteto „Mokymasis visą gyvenimą"VP1-2.2-ŠMM-07-K „Studijų kokybės gerinimas, tarptautiškumo didinimas", atnaujinamų studijų programų tarpinio vertinimo reikalavimai, kriterijai, patvirtinti Lietuvos Respublikos Švietimo ir mokslo ministerijos ịsakymu Nr. SR-28-01-299, 2010-09-30.

2007-2013 m. Žmogiškụjų išteklių plètros veiksmų programos 2 prioriteto "Mokymasis visą gyvenimą" VP12.2-ŠMM-07-K priemonès „Studijų kokybès gerinimas, tarptautiškumo didinimas" projektų finansavimo sąlygų aprašas Nr. 2, patvirtintas Lietuvos Respublikos švietimo ir mokslo ministro įsakymu Nr. V-1542. (Žin., 2010-03, Nr. 108-5572; 2011-03-19, Nr. 33-1563; 2011-09-08, Nr. 1115246).

Weeden P., Winter J., Broadfoot P. (2005). Vertinimas. Ka tai reiškia mokykloms? Vilnius.

Windle Ch., Ochberg F. M. (1975). Evaluation overview Enhancing program evaluation in the Community Mental Health Centers Program. Evaluation, 2 (2), p. 30-36. JosseyBass Inc. Publishers. San Francisco-Washington-London, New Directions.

Iteikta 2013 m. birželio mèn.

Delivered 2013 June

\section{GINTAUTÉ ŽIBE்NIENÉ}

Mokslinių interesų kryptys: mokymo / studijų kokybės užtikrinimas, studijų programos kokybès vertinimas, vertinimo metodologija, kompetentingumų ir asmens pasiekimų vertinimas, verslumo ugdymas.

Mykolo Romerio universitetas

Socialinių technologiju fakultetas

Edukologijos ir socialinio darbo institutas
Research interests: teaching / study quality assurance, quality assessment of study programmes, assessment methodology, assessment of competences and individual achievements, entrepreneurship development.

Mykolas Romeris University

Faculty of Social Technologies

Institute of Educational Sciences and Social Work

Ateities g. 20, LT-08303, Vilnius, Lithuania

zibeniene@mrunni.eu 